\title{
Is there a role for the quantification of RRM1 and ERCC1 expression in pancreatic ductal adenocarcinoma?
}

\author{
Matias E Valsecchi \\ Thomas Jefferson University \\ Thomas Holdbrook \\ Thomas Jefferson University \\ Benjamin E Leiby \\ Thomas Jefferson University Hospital \\ Edward Pequignot \\ Thomas Jefferson University \\ Sulsaw this kittmandditional works at: https://jdc.jefferson.edu/medoncfp \\ Thomas Jefferson University \\ Part of the Oncology Commons \\ Let us know how access to this document benefits you
}

\section{Recommended Citation}

Valsecchi, Matias E; Holdbrook, Thomas; Leiby, Benjamin E; Pequignot, Edward; Littman, Susan

J; Yeo, Charles; Brody, Jonathan; and Witkiewicz, Angieszka, "Is there a role for the quantification of RRM1 and ERCC1 expression in pancreatic ductal adenocarcinoma?" (2012). Department of Medical Oncology Faculty Papers. Paper 17.

https://jdc.jefferson.edu/medoncfp/17

This Article is brought to you for free and open access by the Jefferson Digital Commons. The Jefferson Digital Commons is a service of Thomas Jefferson University's Center for Teaching and Learning (CTL). The Commons is a showcase for Jefferson books and journals, peer-reviewed scholarly publications, unique historical collections from the University archives, and teaching tools. The Jefferson Digital Commons allows researchers and interested readers anywhere in the world to learn about and keep up to date with Jefferson scholarship. This article has been accepted for inclusion in Department of Medical Oncology Faculty Papers by an authorized administrator of the Jefferson Digital Commons. For more information, please contact: JeffersonDigitalCommons@jefferson.edu. 


\section{Authors}

Matias E Valsecchi, Thomas Holdbrook, Benjamin E Leiby, Edward Pequignot, Susan J Littman, Charles Yeo, Jonathan Brody, and Angieszka Witkiewicz 


\title{
Is there a role for the quantification of RRM1 and ERCC1 expression in pancreatic ductal adenocarcinoma?
}

\author{
Matias E Valsecchi ${ }^{1 *}$, Thomas Holdbrook ${ }^{2}$, Benjamin E Leiby ${ }^{3}$, Edward Pequignot ${ }^{3}$, Susan J Littman', Charles J Yeo ${ }^{4}$, \\ Jonathan R Brody ${ }^{5}$ and Agnieszka K Witkiewicz ${ }^{2}$
}

\begin{abstract}
Background: RRM1 and ERCC1 overexpression has been extensively investigated as potential predictive markers of tumor sensitivity to conventional chemotherapy agents, most thoroughly in lung cancer. However, data in pancreatic cancer are scarce.

Methods: We investigated the mRNA and protein expression of ERCC1 and RRM1 by RT-PCR and immunohistochemistry $(\mathrm{IHC})$ in formalin-fixed, paraffin-embedded pancreatic ductal carcinoma (PDA) tissues. The primary outcome investigated was the association between RRM1 and ERCC1 expression and overall survival (OS) or disease-free survival (DFS).

Results: A total of 94 patients with resected PDA were included in this study. Most of them (87\%) received gemcitabine based chemotherapy. Data for OS analysis was available in all cases but only 68\% had enough information to estimate DFS. IHC analysis revealed information for 99\% (93/94) and 100\% of the cases for RRM1 and ERCC1 expression respectively. However, PCR data interpretation was possible in only 49 (52\%) and 79 (84\%) cases respectively. There was no significant association between high or low expression of either RRM1 or ERCC1, detected by $I H C$ and $O S$ (14.4 vs. 19.9 months; $P=0.5$ and 17.1 vs. 19.9; $P=0.83$ respectively) or $P C R$ and OS (48.0 vs. 24.1 months; $P=0.21$ and 22.0 vs. 16.0 months; $P=0.39$ respectively). Similar results were obtained for DFS.

Conclusions: RRM1 and ERCC1 expression does not seem to have a clear predictive or prognostic value in pancreatic cancer. Our data raise some questions regarding the real clinical and practical significance of analyzing these molecules as predictors of outcomes.
\end{abstract}

\section{Background}

Pancreatic ductal adenocarcinoma (PDA) is recognized as the fourth leading cause of cancer-related mortality, being responsible for almost 40,000 deaths per year in the US [1]. Only $20 \%$ of the patients undergo surgical resection and, with the exception of extremely rare circumstances, almost all patients receive some sort of chemotherapy either as neoadjuvant, adjuvant or systemic treatment of metastatic disease. For years, the traditional approach included the use gemcitabine [2] or gemcitabine based combinations $[3,4]$ as the standard of care.

\footnotetext{
* Correspondence: Matias.Valsecchi@jeffersonhospital.org 'Department of Medical Oncology, Thomas Jefferson University, 834 Chestnut Street Suite 320, Philadelphia, PA 19107, USA Full list of author information is available at the end of the article
}

This paradigm was recently challenged by the confirmation that another regimen, which includes a combination of 5-FU, leucovorin, oxaliplatin and irinotecan (FOLFIRINOX) was superior to single agent gemcitabine in the metastatic setting [5]. However this benefit was also accompanied by a significant increase in grade 3-4 toxicity. This generates a practical clinical dilemma, especially in those patients who have poor performance status and may not be able to tolerate this regimen. In that sense, information regarding the tumor sensitivity to gemcitabine - and to oxaliplatin - may have useful clinically practical implications [6]. The ribonucleotide reductase subunit M1 (RRM1) and the excision repair cross complementary 1 (ERCC1) enzymes are two of the many proteins that physiologically participate in the synthesis

\section{Biomed Central}


and damage repair of human DNA. Both molecules have been extensively investigated as potential predictive markers of tumor sensitivity to conventional chemotherapy agents. RRM1 is directly affected by gemcitabine, constituting one of its molecular targets [7]. RRM1 inhibition translates into reduced activity of the ribonucleotide reductase complex resulting in decreased production of deoxyribonucleotides needed for the DNA synthesis [8]. It is consequently easy to understand that over-expression of RRM1 can result in gemcitabine resistance [9]. ERCC1, on the other hand, seems to play a more relevant role in the repair of DNA damage resulting from intra and interstrand cross links [10]. Platinum analogues, as a group, exert much of their therapeutic effects through the induction of DNA adducts and cross-links [11]. Consequently, over-expression of ERCC1 and other enzymes able to remove those DNA adducts can translate into tumoral resistance to platinum analogues $[12,13]$. These two phenomenon have been consistently found to be true especially in non-small cell lung cancer (NSCLC) [14-19]; however it is unclear whether the same concept can be applied to other cancer types, such as PDA. Moreover, it is also uncertain whether high levels of expression of RRM1 and ERCC1 carry any prognostic significance independently of the type of chemotherapy used. At least one previous study showed a better overall survival associated with high levels of RRM1 and ERCC1 in resected
PDA [20]. However, this work was never validated in an independent cohort and the sample size was small.

We designed the present clinical study with the objective to determine whether quantification of RRM1 and ERCC1 by immunohistochemical (IHC) and quantitative-PCR analysis has any prognostic or predictive significance in PDA.

\section{Methods}

\section{Patient selection and data collection}

We studied 94 patients with confirmed PDA who underwent surgical resection at The Thomas Jefferson University Hospital between 2002 and 2010, and for whom sufficient material was available for immunohistochemical (IHC) and polymerase chain reaction (PCR) analysis. All had consented to analyses of their tumors via a protocol approved by the Thomas Jefferson University Institutional Review Board. We reviewed the medical charts and contacted primary oncologists to obtain relevant clinical information. Vital status was obtained from medical records and verified by querying the Social Security death index. The following variables were obtained for analysis: age, gender, tumor size and grade, number of lymph nodes resected, number of lymph nodes metastases, resection margin involvement by tumoral cells, type of treatment received (type of surgery, radiation therapy and chemotherapy), time and site of first recurrence and death.

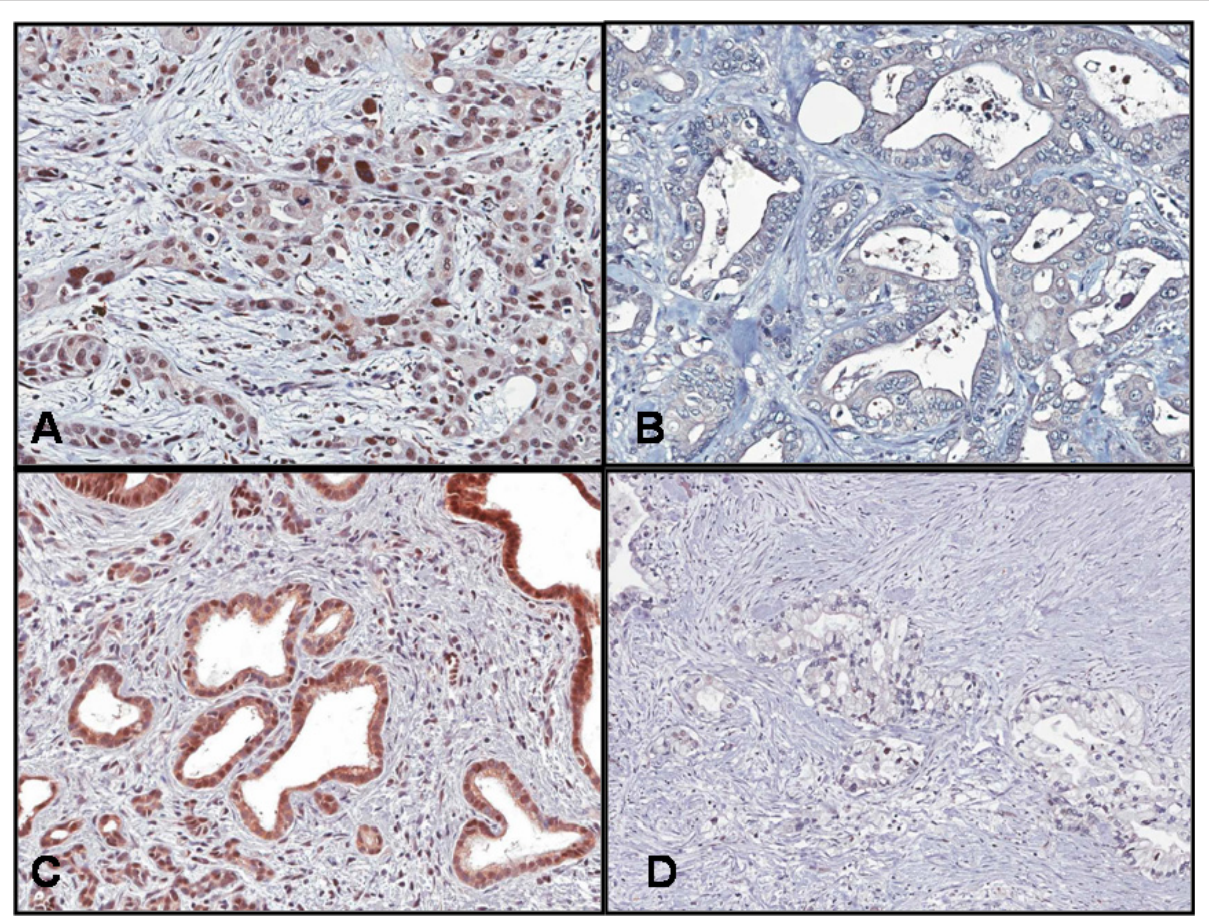

Figure 1 Staining for RRM1 and ERCC1 proteins. (A) ERCC1-positive sample. Note the intense nuclear staining. (B) ERCC1-negative sample. (C) RRM1-positive sample. Note the intense cytoplasmic staining. (D) RRM1-negative sample. 
To ensure accuracy, dual data extraction was conducted. Data were subsequently verified between the reviewers and discrepancies resolved through consensus discussion. To minimize subjective judgment and selection bias, reviewers were blinded to clinical outcomes.

\section{Immunohistochemical and PCR analysis}

We investigated the mRNA and protein expression of ERCC1 and RRM1 by RT-qPCR and immunohistochemistry (IHC) in formalin-fixed, paraffin- embedded PDA tissues. Samples were sent by the investigators to Response Genetics (Los Angeles, CA). Relative gene expression quantification was calculated according to the comparative cycle threshold $(\mathrm{Ct})$ method using $\mathrm{B}$-actin as an endogenous control and commercial RNA controls (Stratagene, La Jolla, CA) as calibrators. Samples were classified as "Low" or "High" expression according to cut off values pre-established by Response Genetics (Los Angeles, CA) [21]. The pancreatic cancer cases originally tested by Response Genetic to establish those cuts off values were not included in the study.

IHC was performed using purified RRM1 antibody (1:150 dilution; Abcam, Cambridge, MA) and ERCC1 antibody (1:50 dilution; Abcam, Cambridge, MA). RRM1 and ERCC1 immunoreactivity was evaluated semi-quantitatively based on staining intensity and proportion of staining in five representative fields at $400 \times$ magnification. ERCC1 was evaluated based on nuclear staining and RRM1 based on cytoplasmic staining (Figure 1). The stained tumor tissues were scored blindly with respect to clinical patient data. For RRM1, the proportion of staining was scored on a scale from 0 to 3 as follows: $>=50 \%$ positive (score 3 ); $10-49 \%$ positive (score 2 ); $1-9 \%$ positive (score 1); negative (score 0 ). The intensity of staining was scored from 0 to 3 as follows: 0 (absent), 1 (weak), 2 (moderate), 3 (intense). For ERCC1, the proportion of staining was scored on a scale from 0 to 4 as follows: $>50 \%$ positive (score 4$) ; 25-50 \%$ positive (score 3 ); $10-24 \%$ positive (score 2 ); $1-9 \%$ positive (score 1 ); negative (score 0$)$. The intensity of staining was scored from 0 to 3 as follows: 0 (absent), 1 (weak), 2 (moderate), 3 (intense) [12]. The immunoreactive score for each case was determined by multiplying the proportion and intensity scores. Criteria for positive staining were modeled after previous work, requiring immunoreactive scores of 9 out of 9 and 6 out of 12 to be considered positive - or high expression - for RRM1 and ERCC1, respectively [22,23].

\section{Outcomes and statistical analysis}

The primary outcome was the association between RRM1 and ERCC1 expression - dichotomized as high or low and overall survival (OS) or disease-free survival (DFS). OS was defined from the day of surgery to the day of death or last follow-up. DFS was defined from the day of surgery to the day of the first documented relapse or death or last follow -up. Secondary outcomes include the correlation between the IHC and PCR results found for RRM1 and ERCC1 expression.

Patient characteristics were summarized using medians and ranges for continuous variables and frequencies and percentages for categorical variables. The distribution of OS and DFS times was estimated using the Kaplan-Meier method. The log-rank test was used to identify patient and tumor characteristics significantly associated with OS and DFS. Chi-square tests were used to identify covariates associated with RRM1 and ERCC1 expression. Cox proportional hazards regression was used to test for

Table 1 Clinico-pathologic characteristics of the 94 patients

\begin{tabular}{|c|c|c|}
\hline Characteristics & $\mathrm{N}^{\circ}$ of Patients (\%) & Median (range) \\
\hline Age (years) & 94 & 66 (35-89) \\
\hline \multicolumn{3}{|l|}{ Gender } \\
\hline Male & $53(56 \%)$ & \\
\hline Female & $41(44 \%)$ & \\
\hline Size, $\mathrm{cm}$ & & $3(0-9.5)$ \\
\hline \multicolumn{3}{|l|}{ Histological Grade } \\
\hline 1 & $5(5 \%)$ & \\
\hline 2 & $69(73 \%)$ & \\
\hline 3 & $18(19 \%)$ & \\
\hline 4 & $1(1 \%)$ & \\
\hline$(U n k n o w n)^{¥}$ & $1(1 \%)$ & \\
\hline \multicolumn{3}{|l|}{ Tumor Size (T) } \\
\hline $1-2$ & $15(16 \%)$ & \\
\hline $3-4$ & 78 (83\%) & \\
\hline$(\text { Unknown })^{¥}$ & $1(1 \%)$ & \\
\hline \multicolumn{3}{|l|}{ Nodes (N) } \\
\hline Positive & $65(69 \%)$ & \\
\hline Negative & $27(29 \%)$ & \\
\hline$(\text { Unknown })^{¥}$ & $2(2 \%)$ & \\
\hline \multicolumn{3}{|l|}{ TNM Stage } \\
\hline IA & $2(2 \%)$ & \\
\hline $\mathrm{IB}$ & $3(3 \%)$ & \\
\hline$\| \mathrm{A}$ & $21(22 \%)$ & \\
\hline$\| \mathrm{B}$ & $63(67 \%)$ & \\
\hline III & $3(3 \%)$ & \\
\hline IV & $2(2 \%)$ & \\
\hline
\end{tabular}

\begin{tabular}{cc} 
Resection Margins & \\
R0 & $66(70 \%)$ \\
R1 & $27(29 \%)$ \\
(Unknown) & $1(1 \%)$ \\
\hline Vital status & $34(36 \%)$ \\
Alive & $60(64 \%)$ \\
Dead &
\end{tabular}

¥ This corresponds with patients with metastatic disease for whom this variable could not be obtained 
association of RRM1 and ERCC1 expression with OS after adjustment for potential confounders. Spearman rank correlations were calculated to test for association among RRM1 and ERCC1 gene expression levels and IHC scores.

\section{Results}

A total of 94 patients were included in this study, with a median age of 65 years (range: $35-89$ years). The median follow up was 15 months. The baseline clinic-pathologic characteristics of the patients are summarized in Table 1. From the whole cohort, $87.2 \%$ (82 cases) received gemcitabine based chemotherapy and in 12 cases chemotherapy was not administered. Data for OS analysis were available in all cases but only 64 patients $(68 \%)$ had enough information to estimate DFS. IHC analysis revealed information for 99\% (93/94) and 100\% of the cases for RRM1 and ERCC1 expression, respectively. However, PCR data interpretation was possible only in 49 (52\%) and 79 (84\%) cases respectively.

There was no significant difference between high or low expression of either RRM1 or ERCC1, detected by IHC or PCR, and any of the clinic-pathological variables analyzed, which included age, race, gender, tumor size, pathological depth (pT), histological grade and presence of metastatic lymph nodes (Table 2).
The median survival of the entire cohort was 18 months (CI: 14-25). In the univariate analysis the variables associated with better OS were younger age $(<65.5$ years; $P=0.087)$, histological grade 1 or $2(P=0.003)$, absence of lymph node metastases $(P=0.009)$ and use of chemotherapy $(P<0.001)$. However, there was no significant association between high or low expression of either RRM1 or ERCC1, detected by IHC and OS (14.4 vs. 19.9 months; $P=0.5$ and 17.1 vs. $19.9 ; P=0.83$ respectively) or PCR and OS (48.0 vs. 24.1 months; $P=0.21$ and 22.0 vs. 16.0 months; $P=0.39$ respectively) (Figures 2 and 3 ). Similar results were obtained with DFS where only histological grade 1 or $2(P=0.031)$, absence of lymph node metastases $(P=0.08)$ and use of chemotherapy $(P=$ $0.013)$ showed significant longer DFS. The same as in OS, the expression levels of RRM1 or ERCC1 detected by IHC or by PCR did not showed any statistically significant result (Table 3). Using Cox regression multivariate analysis the expression levels of RRM1 and ERCC1 were not significant associated with any change in the OS or the DFS using IHC (Table 4). RRM1 was associated with OS using PCR after adjustment for other predictors of survival. The exclusion of the 12 patients who did not receive a full course of chemotherapy did not make any significant change in the estimates (Table 5).

Table 2 Covariates and RRM1 or ERCC1 (Patient N, row\%)

\begin{tabular}{|c|c|c|c|c|c|c|c|c|c|c|c|c|c|c|c|c|}
\hline \multirow[b]{3}{*}{ Covariate } & \multicolumn{8}{|c|}{ RRM1 Expression } & \multicolumn{8}{|c|}{ ERCC1 Expression } \\
\hline & \multicolumn{2}{|c|}{$\begin{array}{l}\text { RRM1 mRNA } \\
\text { expression (PCR) }\end{array}$} & \multicolumn{4}{|c|}{$\begin{array}{l}\text { RRM1 protein } \\
\text { expression (IHC) }\end{array}$} & \multirow[b]{2}{*}{$\mathbf{N}$} & \multirow[b]{2}{*}{$p$} & \multicolumn{2}{|c|}{$\begin{array}{l}\text { ERCC1 mRNA } \\
\text { expression (PCR) }\end{array}$} & \multicolumn{4}{|c|}{$\begin{array}{l}\text { ERCC1 protein } \\
\text { expression (IHC) }\end{array}$} & \multirow[b]{2}{*}{$\mathbf{N}$} & \multirow[b]{2}{*}{$p$} \\
\hline & High & Low & $\mathbf{N}$ & $p$ & High & Low & & & High & Low & $\mathbf{N}$ & $p$ & High & Low & & \\
\hline \multicolumn{17}{|l|}{ Age (years) } \\
\hline Young $(\leq 65.5)$ & $4(21 \%)$ & 15 (79\%) & 49 & 1.0 & $14(30 \%)$ & $32(70 \%)$ & 93 & 0.51 & $19(48 \%)$ & $21(53 \%)$ & 79 & 0.36 & $29(62 \%)$ & $18(38 \%)$ & 94 & 0.41 \\
\hline Old $(>65.5)$ & $6(20 \%)$ & $24(80 \%)$ & & & $18(38 \%)$ & $29(62 \%)$ & & & $14(36 \%)$ & $25(64 \%)$ & & & $24(51 \%)$ & $23(49 \%)$ & & \\
\hline \multicolumn{17}{|l|}{ Size $(\mathrm{cm})$} \\
\hline Small $(\leq 2.0)$ & $1(9 \%)$ & $10(91 \%)$ & 49 & 0.42 & $5(26 \%)$ & $14(74 \%)$ & 93 & 0.59 & $4(31 \%)$ & $9(69 \%)$ & 79 & 0.54 & $11(55 \%)$ & $9(45 \%)$ & 94 & 1.0 \\
\hline Large (> 2.0) & $9(24 \%)$ & $29(76 \%)$ & & & $27(36 \%)$ & $47(64 \%)$ & & & $29(44 \%)$ & $37(56 \%)$ & & & $42(57 \%)$ & $32(43 \%)$ & & \\
\hline \multicolumn{17}{|l|}{ Gender } \\
\hline Female & $6(24 \%)$ & 19 (76\%) & 49 & 0.73 & $14(35 \%)$ & $26(65 \%)$ & 93 & 1.0 & $13(37 \%)$ & $22(63 \%)$ & 79 & 0.50 & $25(61 \%)$ & $16(39 \%)$ & 94 & 0.53 \\
\hline Male & $4(17 \%)$ & $20(83 \%)$ & & & $18(34 \%)$ & $35(66 \%)$ & & & $20(45 \%)$ & $24(55 \%)$ & & & $28(53 \%)$ & $25(47 \%)$ & & \\
\hline \multicolumn{17}{|l|}{ Race } \\
\hline White & $4(12 \%)$ & $29(88 \%)$ & 48 & 0.11 & $23(35 \%)$ & $43(65 \%)$ & 92 & 1.0 & $22(42 \%)$ & $31(58 \%)$ & 78 & 1.0 & $36(55 \%)$ & $30(45 \%)$ & 93 & 0.82 \\
\hline Non-White & $5(33 \%)$ & $10(67 \%)$ & & & $9(35 \%)$ & $17(65 \%)$ & & & $11(44 \%)$ & $14(56 \%)$ & & & $16(59 \%)$ & $11(41 \%)$ & & \\
\hline \multicolumn{17}{|c|}{ Histological Grade } \\
\hline 1 or 2 & $7(19 \%)$ & $29(81 \%)$ & 48 & 1.0 & $22(30 \%)$ & $51(70 \%)$ & 92 & 0.10 & $27(45 \%)$ & $33(55 \%)$ & 78 & 0.43 & $42(57 \%)$ & $32(43 \%)$ & 93 & 0.80 \\
\hline 3 or 4 & $2(17 \%)$ & $10(83 \%)$ & & & $10(53 \%)$ & $9(47 \%)$ & & & $6(33 \%)$ & $12(67 \%)$ & & & $10(53 \%)$ & $9(47 \%)$ & & \\
\hline \multicolumn{17}{|c|}{ Lymph Nodes ${ }^{¥}$} \\
\hline No LN positive & $4(31 \%)$ & $9(69 \%)$ & 47 & 0.24 & $9(35 \%)$ & $17(65 \%)$ & 91 & 1.0 & $14(64 \%)$ & $8(36 \%)$ & 77 & 0.024 & $16(59 \%)$ & $11(41 \%)$ & 92 & 0.82 \\
\hline At least 1 LN positive & $5(15 \%)$ & $29(85 \%)$ & & & $23(35 \%)$ & $42(65 \%)$ & & & $19(35 \%)$ & $36(65 \%)$ & & & $36(55 \%)$ & $29(45 \%)$ & & \\
\hline \multicolumn{17}{|l|}{ Depth of Tumor (pT) ${ }^{¥}$} \\
\hline T1 and T2 & $2(20 \%)$ & $8(80 \%)$ & 48 & 1.0 & $4(27 \%)$ & $11(73 \%)$ & 92 & 0.56 & $4(36 \%)$ & $7(64 \%)$ & 78 & 0.75 & $5(33 \%)$ & $10(67 \%)$ & 93 & 0.087 \\
\hline $\mathrm{T} 3$ and $\mathrm{T} 4$ & $7(18 \%)$ & $31(82 \%)$ & & & $28(36 \%)$ & $49(64 \%)$ & & & $29(43 \%)$ & $38(57 \%)$ & & & $47(60 \%)$ & $31(40 \%)$ & & \\
\hline
\end{tabular}

\footnotetext{
¥ The difference in values corresponds to the patients with metastatic disease only, for whom some variables were not able to be computed.
} 


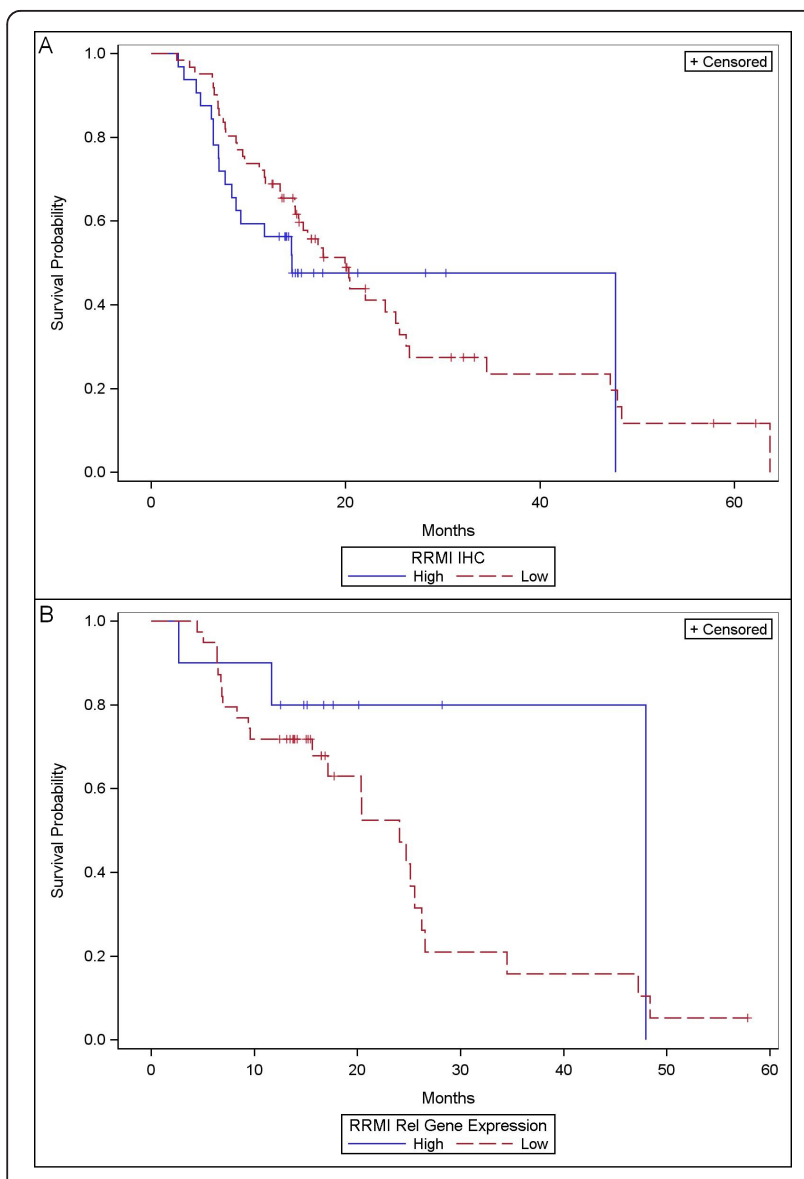

Figure 2 Kaplan Meier curve for overall survival according RRM1 expression by: A) - IHC $(P=0.5)$ and $B)$ - PCR $(P=0.21)$.

In regards to the correlation between IHC and PCR analysis, we found a borderline significant association between RRM1 expression by IHC and PCR $(r=0.26$; $P=0.07)$ and the same result was applicable for ERCC1 expression $(\mathrm{r}=0.21 ; P=0.07)$. However there was a strong positive correlation between the RRM1 and the ERCC1 gene expression detection by PCR $(\mathrm{r}=0.57 ; P<$ 0.0001) (Table 6).

\section{Discussion}

The results obtained in this study showed no significant correlation between the protein or mRNA expression levels of RRM1 and ERCC1 - detected by IHC or PCR and OS or DFS in patients with resected PDA. Our data raise some questions regarding the real clinical and practical significance of analyzing these molecules as predictors of outcomes. Low levels of RRM1 did not predict better outcomes which, since the majority of our patients received gemcitabine based chemotherapy regimens, would have indirectly represented more tumor sensitivity to this agent.

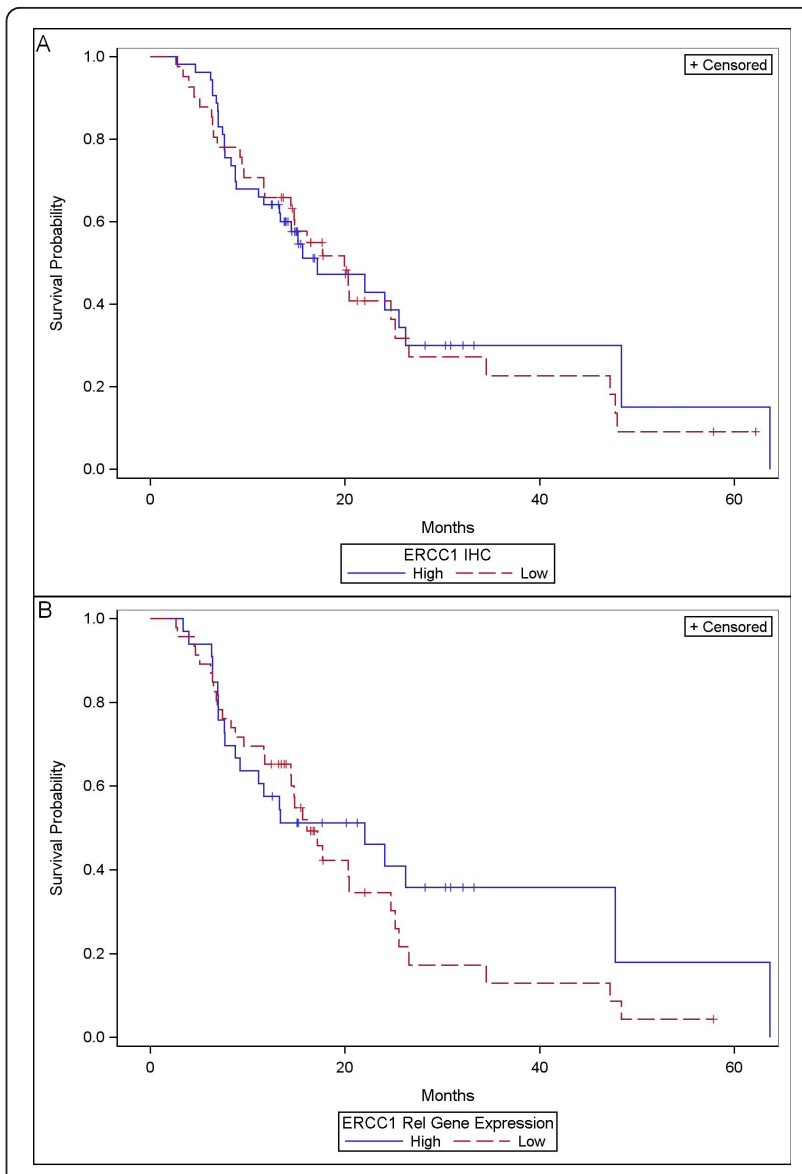

Figure 3 Kaplan Meier curve for overall survival according ERCC1 expression by: $\mathrm{A})$ - IHC $(P=0.83)$ and $\mathrm{B})$ - PCR $(P=$ 0.39).

The role of ERCC1 in PDA is less clear and since practically no patient received platinum analogue agents in this cohort, we cannot deduce the importance of ERCC1 as a predictor of oxaliplatin-based regimens as previously suggested $[24,25]$. Yet it seems to be clear that ERCC1 expression levels do not have any prognostic value in this patient cohort who did not receive platinum based chemotherapy. Future investigations should explore the significance of ERCC1 in patients receiving platinum based regimens.

Our results are discordant with what was previously reported by Akita and colleagues who found borderline better outcomes in patients with high expression levels of RRM1 and ERCC1 [20]. Nonetheless, in that study only a minority of patients received adjuvant chemotherapy (5/ 68 ) and in total only $40 \%$ received gemcitabine during the course of their treatment. Our population is unique and quite different to this previous work since the majority of our patients $(87 \%)$ received gemcitabine in the adjuvant setting. Our study is more in accordance and relevant to current practices in the U.S. (i.e., standard of care therapy); hence our conclusions are directly 
Table 3 Univariate Overall and Disease-Free Survival: Kaplan-Meier medians and log-rank test

\begin{tabular}{|c|c|c|c|c|c|c|c|c|c|}
\hline \multirow[b]{2}{*}{ Covariate } & & \multicolumn{4}{|c|}{ Overall Survival } & \multicolumn{4}{|c|}{ Disease-Free Survival } \\
\hline & & $\begin{array}{l}\text { Median [months] }(95 \% \\
\mathrm{Cl})\end{array}$ & $\mathbf{N}$ & $\begin{array}{c}\text { Total } \\
\mathrm{N}\end{array}$ & $\begin{array}{l}\text { Log-rank } p \text { - } \\
\text { value }\end{array}$ & $\begin{array}{c}\text { Median [months] }(95 \% \\
\mathrm{Cl})\end{array}$ & $\mathbf{N}$ & $\begin{array}{c}\text { Total } \\
\mathrm{N}\end{array}$ & $\begin{array}{l}\text { Log-rank } p \text { - } \\
\text { value }\end{array}$ \\
\hline Overall & & $18(14,25)$ & 94 & 94 & & $12(8,19)$ & 64 & 64 & \\
\hline \multirow[t]{2}{*}{ Age (year) } & $\underset{65.5)}{\text { Young }}(\leq$ & $20(16,47)$ & 47 & 94 & 0.087 & $11(8,19)$ & 38 & 64 & 0.71 \\
\hline & Old (> 65.5) & $15(9,24)$ & 47 & & & $14(7,25)$ & 26 & & \\
\hline \multirow[t]{2}{*}{ Size $(\mathrm{cm})$} & Small $(\leq 2.0)$ & $25(9,47)$ & 20 & 94 & 0.60 & $21(8, \infty)$ & 12 & 64 & 0.17 \\
\hline & Large $(>2.0)$ & $17(13,22)$ & 74 & & & $11(7,17)$ & 52 & & \\
\hline \multirow[t]{2}{*}{ Gender } & Female & $20(12,34)$ & 41 & 94 & 0.89 & $10(7,17)$ & 32 & 64 & 0.12 \\
\hline & Male & $18(12,25)$ & 53 & & & $19(9,46)$ & 32 & & \\
\hline \multirow[t]{2}{*}{ Race } & White & $17(13,26)$ & 66 & 93 & 0.65 & $14(8,25)$ & 43 & 64 & 0.59 \\
\hline & NonWhite & $22(8,26)$ & 27 & & & $10(6,19)$ & 21 & & \\
\hline \multirow[t]{2}{*}{ Grade } & $1 / 2$ & $20(16,26)$ & 74 & 93 & 0.003 & $14(10,19)$ & 52 & 64 & 0.031 \\
\hline & $3 / 4$ & $7(6,14)$ & 19 & & & $6(2,25)$ & 12 & & \\
\hline \multirow{2}{*}{$\begin{array}{l}\text { Lymph } \\
\text { Nodes }\end{array}$} & 0 & $26(22,48)$ & 27 & 92 & 0.009 & $21(14, \infty)$ & 20 & 63 & 0.008 \\
\hline & $\geq 1$ & $15(12,20)$ & 65 & & & $9(7,12)$ & 43 & & \\
\hline $\begin{array}{l}\text { Tumor size } \\
\text { by }\end{array}$ & $1 / 2$ & $12(6,22)$ & 15 & 93 & 0.45 & $19(5, \infty)$ & 9 & 64 & 0.31 \\
\hline TNM stage & $3 / 4$ & $18(15,26)$ & 78 & & & $11(8,19)$ & 55 & & \\
\hline \multirow[t]{2}{*}{ Treatment } & Chemo & $20(15,26)$ & 82 & 94 & $<.001$ & $14(9,19)$ & 62 & 64 & 0.013 \\
\hline & No chemo & $6(3, \infty)$ & 12 & & & 5 & 2 & & \\
\hline RRM1 & Low & $20(15,25)$ & 61 & 93 & 0.50 & $12(8,21)$ & 40 & 63 & 0.76 \\
\hline IHC Interp. & High & $14(8,48)$ & 32 & & & $17(5, \infty)$ & 23 & & \\
\hline RRM1 & Low & $24(16,26)$ & 39 & 49 & 0.21 & $14(8,21)$ & 28 & 34 & 0.48 \\
\hline PCR Interp. & High & $48(3,48)$ & 10 & & & $17(11,17)$ & 6 & & \\
\hline ERCC & Low & $20(12,25)$ & 41 & 94 & 0.83 & $14(8,25)$ & 26 & 64 & 0.39 \\
\hline IHC Interp. & High & $17(12,26)$ & 53 & & & $12(7,19)$ & 38 & & \\
\hline ERCC & Low & $16(12,25)$ & 46 & 79 & 0.39 & $10(7,19)$ & 29 & 56 & 0.74 \\
\hline PCR Interp. & High & $22(9,48)$ & 33 & & & $14(6,21)$ & 27 & & \\
\hline
\end{tabular}

Abbreviations: $\infty=$ infinity; Interp. = Interpretation

applicable to the majority of patients who seek medical attention after a resection of a PDA. However the median OS in our cohort (18 months) was slightly inferior to that previously reported in randomized clinical trials (i.e.: in Conko-001, 22 months) [26]; this could be attributed to the more heterogeneous population of our study in comparison to one that could be observed in prospective and controlled clinical trials.

There are some studies that support the role of RRM1 over-expression as a source of resistance to gemcitabine in PDA $[27,28]$. One study showed that in gemcitabine resistant cell lines, sensitivity to this agent could be rescued by silencing the RRM1 expression (> 90\%) with iRNA [10]. A similar correlation between RRM1 expression and gemcitabine efficacy was observed in the clinical setting but only in NSCLC [16]. However, during the last couple of years many other genes have been described as potential source of gemcitabine resistance in pancreatic tumoral cells, including human equilibrative nucleoside transporter-1
(hENT1) [29,30], deficiency in deoxycytidine kinase (dCK) [31], over-expression of RRM2 [32] and HuR [6,33]. The roles played by each particular gene in addition to the possible still undiscovered genes and pathways in the gemcitabine metabolism process, coupled with the complex invivo environment, are still under investigation [34]. However, some studies have already shown that the combination of detecting the expression of a select set of genes rather than the particular expression of one gene may play a more relevant, realistic clinical role [35,36]. Moreover, our own group has previously shown a notoriously more predictive value of HuR for gemcitabine sensitivity, which is most likely due to its ability to affect a myriad of downstream target genes [33]. Additionally, a recent report found also no prognosis value of RRM1 in PDA [37]

Taking all this evidence together, in conjunction with the results of the present study, we believe that the isolated detection of RRM1 or ERCC1 expression in PDA has little clinical relevance and deserves further 
Table 4 Multivariate cox regression analysis for overall survival

\begin{tabular}{|c|c|c|c|}
\hline \multicolumn{4}{|c|}{ A. Survival in Pancreatic CA: Relative Gene Expression ( $\mathrm{N}=42$ ) } \\
\hline \multirow{2}{*}{\multicolumn{2}{|c|}{ Variable (Comparison) }} & \multicolumn{2}{|c|}{ Multivariate } \\
\hline & & $\begin{array}{c}\text { Hazard Ratio } \\
(95 \% \mathrm{Cl})\end{array}$ & \multirow{2}{*}{$\begin{array}{c}\boldsymbol{p} \text {-value } \\
0.836\end{array}$} \\
\hline Year of Diagnosis & one year increase & $0.97(0.69,1.35)$ & \\
\hline Age & $\geq 65.5$ vs. $<65.5$ & $1.53(0.54,4.33)$ & 0.419 \\
\hline Positive Lymph Nodes & Any vs. None & $0.80(0.29,2.22)$ & 0.672 \\
\hline Treatment received & No Chemo vs. Chemo & $13.09(1.71,100.2)$ & 0.013 \\
\hline ERCC1 Rel Gene Expression (PCR) & Low vs. High & $0.86(0.26,2.81)$ & 0.797 \\
\hline RRM1 Rel Gene Expression (PCR) & Low vs. High & $17.58(1.45,213.5)$ & 0.024 \\
\hline \multicolumn{4}{|c|}{ B. Survival in Pancreatic CA: Protein Expression by IHC Score $(\mathrm{N}=91)$} \\
\hline & & \multicolumn{2}{|c|}{ Multivariate } \\
\hline \multicolumn{2}{|c|}{ Variable (Comparison) } & $\begin{array}{l}\text { Hazard Ratio } \\
(95 \% \mathrm{Cl})\end{array}$ & $p$-value ${ }^{\dagger}$ \\
\hline Year of Diagnosis & one year increase & $0.86(0.71,1.02)$ & 0.088 \\
\hline Age & $\geq 65.5$ vs. $<65.5$ & $1.36(0.74,2.52)$ & 0.320 \\
\hline Positive Lymph Nodes & Any vs. None & $2.34(1.21,4.52)$ & 0.011 \\
\hline Treatment & No Chemo vs. Chemo & $3.04(1.25,7.41)$ & 0.014 \\
\hline ERCC1 $1 \mathrm{HC}$ & Low vs. High & $0.96(0.53,1.74)$ & 0.888 \\
\hline RRM1 IHC & Low vs. High & $0.83(0.42,1.63)$ & 0.583 \\
\hline
\end{tabular}

Stratified by Grade

† Cox regression

Table 5 Overall and Disease-Free Survival using Kaplan-Meier and log-rank test but only in patients who received complete chemotherapy regimen (all of whom received gemcitabine)

\begin{tabular}{|c|c|c|c|c|c|c|c|c|c|}
\hline \multirow[b]{2}{*}{ Covariate } & & \multicolumn{4}{|c|}{ Overall Survival } & \multicolumn{4}{|c|}{ Disease-Free Survival } \\
\hline & & Median [months] $(95 \% \mathrm{Cl})$ & $\mathbf{N}$ & Total $\mathbf{N}$ & $\begin{array}{c}\text { Log-rank } \\
p \text {-value }\end{array}$ & Median [months] $(95 \% \mathrm{Cl})$ & $\mathbf{N}$ & Total N & $\begin{array}{c}\text { Log-rank } \\
p \text {-value }\end{array}$ \\
\hline Overall & & $20.3(15,25.5)$ & 82 & 82 & & $13.5(9.3,19.4)$ & 62 & 62 & \\
\hline \multirow[t]{2}{*}{ Age } & Young $(\leq 65.5)$ & $22(15.6,47.2)$ & 44 & 82 & 0.18 & $10.5(8,19.3)$ & 38 & 62 & 0.48 \\
\hline & Old (> 65.5) & $17(9.6,25.5)$ & 38 & & & $14(8, \infty)$ & 24 & & \\
\hline \multirow[t]{2}{*}{ Size } & Small $(\leq 2.0)$ & $25(9.6,47.2)$ & 18 & 82 & 0.45 & $20.5(8.3, \infty)$ & 12 & 62 & 0.21 \\
\hline & Large $(>2.0)$ & $17.7(14.8,25.5)$ & 64 & & & $12(8,17.3)$ & 50 & & \\
\hline \multirow[t]{2}{*}{ Gender } & Female & $22(14.8,34.5)$ & 36 & 82 & 0.85 & $10(6.5,17.3)$ & 31 & 62 & 0.12 \\
\hline & Male & $20(14.4,25.5)$ & 46 & & & $19.3(9.4,46)$ & 31 & & \\
\hline \multirow[t]{2}{*}{ Race } & White & $20(14.8,26.5)$ & 59 & 82 & 0.88 & $13.5(8,25.5)$ & 42 & 62 & 0.65 \\
\hline & Non-White & $22(9.2,26.2)$ & 23 & & & $10.3(5.5,592)$ & 20 & & \\
\hline \multirow[t]{2}{*}{ Grade } & $1 / 2$ & $20.5(16,25.5)$ & 67 & 82 & 0.028 & $14(10.3,20.5)$ & 51 & 62 & 0.0503 \\
\hline & $3 / 4$ & $14.5(6.5,26.5)$ & 15 & & & $9.4(2,25.5)$ & 11 & & \\
\hline \multirow[t]{2}{*}{ Lymph Nodes } & 0 & $25.5(15,48.5)$ & 26 & 81 & 0.038 & $20.5(13.5, \infty)$ & 20 & 61 & 0.012 \\
\hline & $\geq 1$ & $16(13,20.3)$ & 55 & & & $9.4(6.5,14)$ & 41 & & \\
\hline Tumor & $1 / 2$ & $20(6.5,47)$ & 13 & 82 & 0.59 & $19.5(5.5, \infty)$ & 8 & 62 & 0.21 \\
\hline (TNM) & $3 / 4$ & $20.5(15,26)$ & 69 & & & $12(8,19.3)$ & 54 & & \\
\hline RRM1 & Low & $20.3(15,25.5)$ & 55 & 81 & 0.87 & $13.5(8,20.5)$ & 39 & 61 & 0.84 \\
\hline IHC Interp & High & $47.8(8.7,48)$ & 26 & & & $16.6(5.5, \infty)$ & 22 & & \\
\hline RRM1 & Low & $24(17,26)$ & 37 & 44 & 0.070 & $14(9.4,25.5)$ & 26 & 32 & 0.62 \\
\hline PCR Interp & High & $48\left({ }^{*}, *\right)$ & 7 & & & $17.3(10.5,17.3)$ & 6 & & \\
\hline$\overline{\text { ERCC }}$ & Low & $20.3(14.8,26.5)$ & 35 & 82 & 0.88 & $14(9.4,31.5)$ & 25 & 62 & 0.36 \\
\hline IHC Interp & High & $17(13.3,26)$ & 47 & & & $12(6.5,20.5)$ & 37 & & \\
\hline ERCC & Low & $17(14.5,24.7)$ & 39 & 68 & 0.23 & $10(7,25.5)$ & 28 & 54 & 0.74 \\
\hline PCR Interp & High & $24(11,63.7)$ & 29 & & & $13.5(8,20.5)$ & 26 & & \\
\hline
\end{tabular}

* The $95 \%$ confidence interval could not be estimated since only one event (death) was recorded. 
Table 6 Correlation of IHC and PCR scores (Spearman Rank Correlation Coefficients)

\begin{tabular}{|c|c|c|c|c|}
\hline & \multicolumn{2}{|c|}{ RRM1 } & \multicolumn{2}{|c|}{ ERCC1 } \\
\hline & RRM1 IHC & RRM1Relative Gene Exp & ERCC1 Relative Gene Exp & ERCC IHC \\
\hline \multirow[t]{3}{*}{ RRM1 IHC } & 1.00 & 0.26 & 0.13 & 0.18 \\
\hline & & $P=0.07$ & $P=0.26$ & $P=0.09$ \\
\hline & $N=93$ & $N=48$ & $N=75$ & $N=93$ \\
\hline RRM1 Rel & & 1.00 & 0.57 & 0.06 \\
\hline \multirow[t]{2}{*}{ Gene Exp } & & & $P<0.0001$ & $P=0.66$ \\
\hline & & $N=49$ & $N=44$ & $N=49$ \\
\hline ERCC1 Rel & & & 1.00 & 0.21 \\
\hline \multirow[t]{2}{*}{ Gene Exp } & & & & $P=0.07$ \\
\hline & & & $N=76$ & $N=76$ \\
\hline \multirow[t]{2}{*}{ ERCC1 IHC } & & & & 1.00 \\
\hline & & & & $N=94$ \\
\hline
\end{tabular}

investigation before formal recommendation regarding its use in clinical practice can be made. In addition, our study also serves as evidence that the information gathered from other tumor types (i.e.: lung cancer) should not always be directly applied to other cancers (especially to PDA where the aggressive biology appears to be unique) without the appropriate confirmation of these assumptions. In the particular cases of NSCLC, this discordance could also be partially explained by the fact that the overall response rate of gemcitabine in PDA is $5-7 \%$ [4] in comparison to the $20 \%$ found in NSCLC [38], meaning that lung cancer is intrinsically more sensitive to gemcitabine and levels of RRM1 may play a more relevant role.

Lastly, we should also take into consideration the fact that our study has some limitations which are mainly derived from its retrospective nature. We were not able to obtain reliable information to calculate DFS in one third of the cases since some patients were lost in follow up or the information available was inaccurate. As expected, this raises some concerns regarding selection bias in our cohort and conclusions regarding this matter should be analyzed cautiously and confirmed in future studies. However, we were able to estimate OS in all cases and, as mentioned before, given the very modest effect of second and third line chemotherapy regimens in PDA it is very unlikely that gross and undetected misbalance of these variables would have changed the results considerably. Additionally, we cannot directly translate our results to the metastatic setting since only 2 patients debuted with a stage IV disease. Other sources of variability could be related to the cut off values used for PCR detection or to the fact that only half of the patients studied had reliable information in regards to the gene expression, thus underscoring the difficulty of realistically utilizing this assay for clinical purposes. Indeed, when analyzing only those patients who received a complete regimen of chemotherapy, high RRM1 gene expression (PCR) showed a trend toward significance $(P=0.07)$ but the number of patients investigated was too small $(\mathrm{N}=$ 7) and results could be due to random sampling variability. We tried to correlate the gene and protein expression levels and we found a borderline significant correlation, but not a direct one. We cannot then discard the possibility that newer and more reliable techniques of gene expression detection could produce different results. Nonetheless, the current available evidence argues against this possibility.

\section{Conclusions}

In conclusion, RRM1 and ERCC1 expression does not seem to have a clear predictive or prognostic value in resected PDA patients. Future studies will elucidate the role of these biomarkers in other tumor types and in PDA patients who present with metastatic disease.

\section{Acknowledgements}

JRB and AKW are supported by a Research Scholar Grant of the American Cancer Society. JRB is also supported by WW Smith Foundation and ACS-IRG grants.

\section{Author details}

'Department of Medical Oncology, Thomas Jefferson University, 834 Chestnut Street Suite 320, Philadelphia, PA 19107, USA. ${ }^{2}$ Department of Pathology, Thomas Jefferson University and the Jefferson Pancreas, Biliary and Related Cancer Center, Philadelphia, PA, USA. ${ }^{3}$ Division of Biostatistics, Department of Pharmacology and Experimental Therapeutics, Thomas Jefferson University, Philadelphia, PA, USA. ${ }^{4}$ Department of Surgery, Thomas Jefferson University, Philadelphia, PA, USA. ${ }^{5}$ Departments of Surgery and Pathology, Thomas Jefferson University, Philadelphia, PA, USA.

\section{Authors' contributions}

MEV participated in the conception and design of the study, collection and assembling of data, data interpretation and drafted the manuscript. TH carried out $I \mathrm{HC}$ and molecularstudies. BEL and EP performed the statistical analyses. SJL participated in the conception and design of the study, data interpretation and drafted the manuscript. CJY participated in the conception and design of the study. JRB participated in the conception and design of the study, data interpretation and drafted the manuscript. AKW 
participated in the conception and design of the study, data interpretation, carried out IHC and molecular studies, and drafted the manuscript. All authors read and approved the final manuscript.

\section{Competing interests}

The authors declare that they have no competing interests.

Received: 17 September 2011 Accepted: 22 March 2012

Published: 22 March 2012

\section{References}

1. Jemal A, Siegel R, Xu J, Ward E: Cancer statistics, 2010. CA Cancer J Clin 2010, 60(5):277-300.

2. Burris HA, Moore MJ, Andersen J, Green MR, Rothenberg ML, Modiano MR, Cripps MC, Portenoy RK, Storniolo AM, Tarassoff P, Nelson R, Dorr FA, Stephens CD, Von Hoff DD: Improvements in survival and clinical benefit with gemcitabine as first-line therapy for patients with advanced pancreas cancer: a randomized trial. J Clin Oncol 1997, 15(6):2403-2413.

3. Moore MJ, Goldstein D, Hamm J, Figer A, Hecht JR, Gallinger S, Au HJ, Murawa P, Walde D, Wolff RA, Campos D, Lim R, Ding K, Clark G, Voskoglou-Nomikos T, Ptasynski M, Parulekar W, National Cancer Institute of Canada Clinical Trials Group: Erlotinib plus gemcitabine compared with gemcitabine alone in patients with advanced pancreatic cancer: a phase III trial of the National Cancer Institute of Canada Clinical Trials Group. J Clin Oncol 2007, 25(15):1960-1966.

4. Heinemann V, Boeck S, Hinke A, Labianca R, Louvet C: Meta-analysis of randomized trials: evaluation of benefit from gemcitabine-based combination chemotherapy applied in advanced pancreatic cancer. BMC Cancer 2008, 8:82.

5. Conroy $T$, Desseigne F, Ychou M, Bouche O, Guimbaud R, Becouarn Y, Adenis A, Raoul JL, Gourgou-Bourgade S, de la Fouchardiere C, Bennouna J, Bachet JB, Khemissa-Akouz F, Pere-Verge D, Delbaldo C, Assenat E, Chauffert B, Michel P, Montoto-Grillot C, Ducreux M, Groupe Tumeurs Digestives of Unicancer, PRODIGE Intergroup: FOLFIRINOX versus gemcitabine for metastatic pancreatic cancer. N Engl J Med 2011, 364(19):1817-1825.

6. Richards NG, Rittenhouse DW, Freydin B, Cozzitorto JA, Grenda D, Rui H, Gonye G, Kennedy EP, Yeo CJ, Brody JR, Witkiewicz AK: HuR status is a powerful marker for prognosis and response to gemcitabine-based chemotherapy for resected pancreatic ductal adenocarcinoma patients. Ann Surg 2010, 252(3):499-505, discussion 505-6.

7. Ueno H, Kiyosawa K, Kaniwa N: Pharmacogenomics of gemcitabine: can genetic studies lead to tailor-made therapy? Br J Cancer 2007, 97(2):145-151

8. Heinemann V, Xu YZ, Chubb S, Sen A, Hertel LW, Grindey GB, Plunkett W: Cellular elimination of 2',2'-difluorodeoxycytidine 5'-triphosphate: a mechanism of self-potentiation. Cancer Res 1992, 52(3):533-539.

9. Nakahira S, Nakamori S, Tsujie M, Takahashi Y, Okami J, Yoshioka S, Yamasaki M, Marubashi S, Takemasa I, Miyamoto A, Takeda Y, Nagano H, Dono K, Umeshita K, Sakon M, Monden M: Involvement of ribonucleotide reductase $\mathrm{M} 1$ subunit overexpression in gemcitabine resistance of human pancreatic cancer. Int J Cancer 2007, 120(6):1355-1363.

10. Volker M, Mone MJ, Karmakar P, van Hoffen A, Schul W, Vermeulen W, Hoeijmakers JH, van Driel R, van Zeeland AA, Mullenders LH: Sequential assembly of the nucleotide excision repair factors in vivo. Mol Cell 2001, 8(1):213-224.

11. Reardon JT, Vaisman A, Chaney SG, Sancar A: Efficient nucleotide excision repair of cisplatin, oxaliplatin, and Bis-aceto-ammine-dichlorocyclohexylamine-platinum(IV) (JM216) platinum intrastrand DNA diadducts. Cancer Res 1999, 59(16):3968-3971.

12. Olaussen KA, Dunant A, Fouret P, Brambilla E, Andre F, Haddad V, Taranchon E, Filipits M, Pirker R, Popper HH, Stahel R, Sabatier L, Pignon JP, Tursz T, Le Chevalier T, Soria JC, IALT Bio Investigators: DNA repair by ERCC1 in non-small-cell lung cancer and cisplatin-based adjuvant chemotherapy. N Engl J Med 2006, 355(10):983-991.

13. Altaha $R$, Liang $X, Y u J J$, Reed E: Excision repair cross complementinggroup 1: gene expression and platinum resistance. Int J Mol Med 2004, 14(6):959-970.

14. Reynolds C, Obasaju C, Schell MJ, Li X, Zheng Z, Boulware D, Caton JR, Demarco LC, O'Rourke MA, Shaw Wright G, Boehm KA, Asmar L, Bromund J, Peng G, Monberg MJ, Bepler G: Randomized phase III trial of gemcitabine-based chemotherapy with in situ RRM1 and ERCC1 protein levels for response prediction in non-small-cell lung cancer. J Clin Oncol 2009, 27(34):5808-5815.

15. Bepler G, Kusmartseva I, Sharma S, Gautam A, Cantor A, Sharma A, Simon G: RRM1 modulated in vitro and in vivo efficacy of gemcitabine and platinum in non-small-cell lung cancer. J Clin Oncol 2006, 24(29):4731-4737.

16. Bepler G, Olaussen KA, Vataire AL, Soria JC, Zheng Z, Dunant A, Pignon JP, Schell MJ, Fouret P, Pirker R, Filipits M, Brambilla E: ERCC1 and RRM1 in the international adjuvant lung trial by automated quantitative in situ analysis. Am J Pathol 2011, 178(1):69-78.

17. Rosell R, Felip E, Taron M, Majo J, Mendez P, Sanchez-Ronco M, Queralt C, Sanchez JJ, Maestre J: Gene expression as a predictive marker of outcome in stage IIB-IIIA-IIIB non-small cell lung cancer after induction gemcitabine-based chemotherapy followed by resectional surgery. Clin Cancer Res 2004, 10(12 Pt 2):4215s-4219s.

18. Aggarwal C, Somaiah N, Simon GR: Biomarkers with predictive and prognostic function in non-small cell lung cancer: ready for prime time? J Natl Compr Canc Netw 2010, 8(7):822-832.

19. Metro G, Zheng Z, Fabi A, Schell M, Antoniani B, Mottolese M, Monteiro AN, Vici P, Lara Rivera S, Boulware D, Cognetti F, Bepler G: In situ protein expression of RRM1, ERCC1, and BRCA1 in metastatic breast cancer patients treated with gemcitabine-based chemotherapy. Cancer Invest 2010, 28(2):172-180.

20. Akita H, Zheng Z, Takeda Y, Kim C, Kittaka N, Kobayashi S, Marubashi S, Takemasa I, Nagano H, Dono K, Nakamori S, Monden M, Mori M, Doki Y, Bepler G: Significance of RRM1 and ERCC1 expression in resectable pancreatic adenocarcinoma. Oncogene 2009, 28(32):2903-2909.

21. Cobo M, Isla D, Massuti B, Montes A, Sanchez JM, Provencio M, Vinolas N, Paz-Ares L, Lopez-Vivanco G, Munoz MA, Felip E, Alberola V, Camps C, Domine M, Sanchez JJ, Sanchez-Ronco M, Danenberg K, Taron M, Gandara D, Rosell R: Customizing cisplatin based on quantitative excision repair cross-complementing 1 mRNA expression: a phase III trial in nonsmall-cell lung cancer. J Clin Oncol 2007, 25(19):2747-2754.

22. Lee S, Park YH, Kim KH, Cho EY, Ahn YC, Kim K, Shim YM, Ahn JS, Park K, Im YH: Thymidine synthase, thymidine phosphorylase, and excision repair cross-complementation group 1 expression as predictive markers of capecitabine plus cisplatin chemotherapy as first-line treatment for patients with advanced oesophageal squamous cell carcinoma. $\mathrm{Br} J$ Cancer 2010, 103(6):845-851.

23. Lee JJ, Maeng CH, Baek SK, Kim GY, Yoo JH, Choi CW, Kim YH, Kwak YT, Kim DH, Lee YK, Kim JB, Kim SY: The immunohistochemical overexpression of ribonucleotide reductase regulatory subunit M1 (RRM1) protein is a predictor of shorter survival to gemcitabine-based chemotherapy in advanced non-small cell lung cancer (NSCLC). Lung Cancer 2010, 70(2):205-210.

24. Mancuso A, Sacchetta S, Saletti PC, Tronconi C, Milesi L, Garassino M, Martelli O, Leone A, Zivi A, Cerbone L, Recine F, Sollami R, Labianca R, Cavalli F, Sternberg CN: Clinical and molecular determinants of survival in pancreatic cancer patients treated with second-line chemotherapy: results of an Italian/Swiss multicenter survey. Anticancer Res 2010, 30(10):4289-4295.

25. Kamikozuru H, Kuramochi H, Hayashi K, Nakajima G, Yamamoto M: ERCC1 codon 118 polymorphism is a useful prognostic marker in patients with pancreatic cancer treated with platinum-based chemotherapy. Int $J$ Oncol 2008, 32(5):1091-1096.

26. Oettle H, Post S, Neuhaus P, Gellert K, Langrehr J, Ridwelski K, Schramm H, Fahlke J, Zuelke C, Burkart C, Gutberlet K, Kettner E, Schmalenberg H, Weigang-Koehler K, Bechstein WO, Niedergethmann M, Schmidt-Wolf I, Roll L, Doerken B, Riess H: Adjuvant chemotherapy with gemcitabine vs observation in patients undergoing curative-intent resection of pancreatic cancer: a randomized controlled trial. JAMA 2007, 297(3):267-277.

27. Kurata N, Fujita H, Ohuchida K, Mizumoto K, Mahawithitwong P, Sakai H, Onimaru M, Manabe T, Ohtsuka T, Tanaka M: Predicting the chemosensitivity of pancreatic cancer cells by quantifying the expression levels of genes associated with the metabolism of gemcitabine and 5-fluorouracil. Int J Oncol 2011, 39(2):473-482.

28. Mitsuno M, Kitajima Y, Ohtaka K, Kai K, Hashiguchi K, Nakamura J, Hiraki M, Noshiro H, Miyazaki K: Tranilast strongly sensitizes pancreatic cancer cells 
to gemcitabine via decreasing protein expression of ribonucleotide reductase 1. Int J Oncol 2010, 36(2):341-349.

29. Mori R, Ishikawa T, Ichikawa Y, Taniguchi K, Matsuyama R, Ueda M, Fujii Y, Endo I, Togo S, Danenberg PV, Shimada H: Human equilibrative nucleoside transporter 1 is associated with the chemosensitivity of gemcitabine in human pancreatic adenocarcinoma and biliary tract carcinoma cells. Oncol Rep 2007, 17(5):1201-1205.

30. Giovannetti E, Del Tacca M, Mey V, Funel N, Nannizzi S, Ricci S, Orlandini C, Boggi U, Campani D, Del Chiaro M, lannopollo M, Bevilacqua G, Mosca F, Danesi R: Transcription analysis of human equilibrative nucleoside transporter-1 predicts survival in pancreas cancer patients treated with gemcitabine. Cancer Res 2006, 66(7):3928-3935.

31. Ohhashi S, Ohuchida K, Mizumoto K, Fujita H, Egami T, Yu J, Toma H, Sadatomi S, Nagai E, Tanaka M: Down-regulation of deoxycytidine kinase enhances acquired resistance to gemcitabine in pancreatic cancer. Anticancer Res 2008, 28(4B):2205-2212.

32. Itoi T, Sofuni A, Fukushima N, Itokawa F, Tsuchiya T, Kurihara T, Moriyasu F, Tsuchida A, Kasuya K: Ribonucleotide reductase subunit M2 mRNA expression in pretreatment biopsies obtained from unresectable pancreatic carcinomas. J Gastroenterol 2007, 42(5):389-394.

33. Costantino CL, Witkiewicz AK, Kuwano Y, Cozzitorto JA, Kennedy EP, Dasgupta A, Keen JC, Yeo CJ, Gorospe M, Brody JR: The role of HuR in gemcitabine efficacy in pancreatic cancer: HuR Up-regulates the expression of the gemcitabine metabolizing enzyme deoxycytidine kinase. Cancer Res 2009, 69(11):4567-4572.

34. Williams TK, Costantino CL, Bildzukewicz NA, Richards NG, Rittenhouse DW Einstein L, Cozzitorto JA, Keen JC, Dasgupta A, Gorospe M, Gonye GE, Yeo CJ, Witkiewicz AK, Brody JR: pp 32 (ANP32A) expression inhibits pancreatic cancer cell growth and induces gemcitabine resistance by disrupting HuR binding to mRNAs. PLoS One 2010, 5(11):e15455.

35. Nakano Y, Tanno S, Koizumi K, Nishikawa T, Nakamura K, Minoguchi M, Izawa T, Mizukami Y, Okumura T, Kohgo Y: Gemcitabine chemoresistance and molecular markers associated with gemcitabine transport and metabolism in human pancreatic cancer cells. Br J Cancer 2007, 96(3):457-463

36. Fujita H, Ohuchida K, Mizumoto K, Itaba S, Ito T, Nakata K, Yu J, Kayashima T, Souzaki R, Tajiri T, Manabe T, Ohtsuka T, Tanaka M: Gene expression levels as predictive markers of outcome in pancreatic cancer after gemcitabine-based adjuvant chemotherapy. Neoplasia 2010, 12(10):807-817.

37. Kim R, Tan A, Lai KK, Jiang J, Wang Y, Rybicki LA, Liu X: Prognostic roles of human equilibrative transporter 1 (hENT-1) and ribonucleoside reductase subunit M1 (RRM1) in resected pancreatic cancer. Cancer 2011, 117(14):3126-3134

38. Sandler A, Ettinger DS: Gemcitabine: single-agent and combination therapy in non-small cell lung cancer. Oncologist 1999, 4(3):241-251.

Pre-publication history

The pre-publication history for this paper can be accessed here: http://www.biomedcentral.com/1471-2407/12/104/prepub

doi:10.1186/1471-2407-12-104

Cite this article as: Valsecchi et al: Is there a role for the quantification of RRM1 and ERCC1 expression in pancreatic ductal adenocarcinoma? BMC Cancer 2012 12:104.

\section{Submit your next manuscript to BioMed Central and take full advantage of:}

- Convenient online submission

- Thorough peer review

- No space constraints or color figure charges

- Immediate publication on acceptance

- Inclusion in PubMed, CAS, Scopus and Google Scholar

- Research which is freely available for redistribution

Submit your manuscript at www.biomedcentral.com/submit 